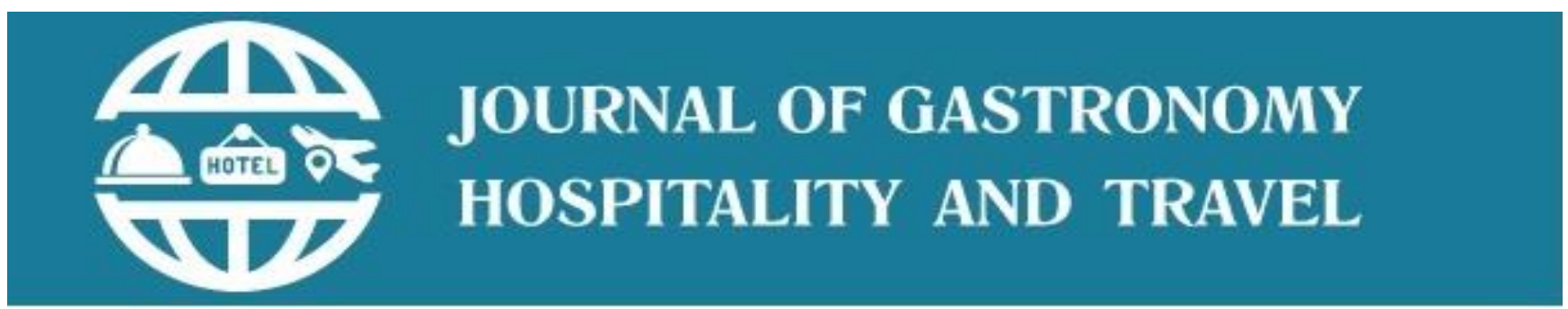

ISSN: $2619-9548$

Journal homepage: www.joghat.org, http://dergipark.gov.tr/joghat

Journal of Gastronomy, Hospitality and Travel (JOGHAT)

2020 - Volume: 3 Number: 1

Page : 51-63

Received:06/05/2020

Revised:08/06/2020

Accepted: $12 / 06 / 2020$

\title{
Research Article \\ CUSTOMERS' PERCEPTIONS, EXPECTATIONS AND EXPERIENCES OF SERVICE QUALITY FOR HOTELS IN MUTARE, ZIMBABWE
}

\author{
Vitalis Basera $^{1}$ (Orcid.org/0000-0002-0705-5974)
}

Godfrey Makandwa² (Orcid.org/0000-0002-0705-5974)

\begin{abstract}
${ }^{1}$ Manicaland State University of Applied Sciences, Department of Tourism and Hospitality, P. Bag 7001 Mutare, Zimbabwe. ${ }^{2}$ Tourism Research in Economics Environs and Society (TREES), School of Management and Economic Sciences, North-West University, Potchefstroom, South Africa
\end{abstract}

\begin{abstract}
This paper aims to expose the customers' perceptions, expectations and experiences of service quality for hotels in Mutare, Zimbabwe. Netnography was used to collect data from Tripadvisor.com posts that were made from December 2018 to January 2020 , the data was analysed using SERVQUAL themes. A total of eight hotels in Mutare city and those within the Vumba mountains trek were selected for this study. Results indicate that there is a difference between customers' perceptions, expectations and experiences of service quality in hotels. A lot is desired to improve the tangibles, responsiveness and reliability in the hotels. It must be noted that the case hotels are not representative of the accommodation providers in Manicaland but representative of themselves. Nonetheless, they provide interesting entry points that help to draw conclusions relating to tourists' views with relation to service quality in Manicaland. The study contributes to service sustainable quality management in hotels from the perspective of customers. A lot is desired to improve the furniture and fitting at the hotels, customer care and standardisation of service provision.
\end{abstract}

Key words: customer perceptions, customer expectations, customer experiences, service quality, hotel,

\section{INTRODUCTION}

In hospitality sector, service quality is integral in satisfying the customers. A customer is delighted if the customers' perceptions and expectations are met or surpassed giving an unforgettable experience. Since hotels are a bigger part the hospitality industry, they should guarantee quality in all seasons of operations. Hospitality industry is an integral and fundamental part of today's world economy; its $4 \%$ growth rate in 2018 has been higher than that of the goods earnings [manufacturing industry] $(+3 \%)$ for seven consecutive years (UNWTO, 2019) indicating the industry's potential to turn around fortune of many economies in the world. A competitive advantage in the hotel industry is gained by satisfying customers, the hotel operators are trying to offer best services by enhancing the level of service quality and performance. Hotel management need to recognise customers' expectations so that they will be able to deliver better service. Alauddin, Ahsan, Mowla, Islam, \& Hossain, (2019)

${ }^{1}$ To cite this document: Basera, V. and Makandwa, G. (2020). Customers' Perceptions, Expectations and Experiences of Service Quality for Hotels in Mutare, Zimbabwe 3(1), 51-63. DOI: 10.33083/joghat.2020.30

Corresponding Author:_vitalisbasera@yahoo.com, gmakandwa05@gmail.com 
note that hotels are now stressing further on the quality standards to meet the rudimentary customers' expectations and perceptions so as to satisfy their custmers' wants and needs.

Satisfying the customer must be one of the main goals through offering better service to the clients in all seasons, 24/7 despite time and circumstances. Successful management of the hotel is premised service quality. In the hotel industry there is competition among operators and for one to be competitive is supposed to deliver the best and superior quality services. A strong market position is also secured by offering quality service. New strategies and policies are being adopted in the hotel industry so as to provide quality services, hotels in Zimbabwe are not an exception. Zimbabwe is full of natural beauty themed "a world of wonders". There are a number of sightseeing spots in the country which includes the mountains (Mt Inyangani), hills (Matopos), cultural heritage sites (Great Zimbabwe monuments), wildlife (Hwanage National Park and Water based (Victoria Falls "Mosi-o-tunya"). Mutare, is a city in the Eastern Highlands of Manicaland which is a gate way to Mozambique. The city is surrounded with beautiful sightseeing spots of Vumba Mountains, Nyangani Mountains, water falls (Mutarazi and Nyachowa), game parks (Nyanga National Park) which makes it a hot spot of travelers. Some of the big resorts are found in Manicaland which include Leopard Rock, Troutbeck and Montclair, these resorts are hotel based. The diverse tourism attractions have to be complemented by quality accommodation in order to enhance guest experiences. This research captures the customers' perspectives and experiences regarding to service quality of accommodation providers, to come up with conclusions and recommendations regarding to the service quality of Manicaland hotels.

\section{LITERATURE REVIEW.}

Kotler \& Armstrong, (2008) defined a service as any activity or benefit that one party can offer to another that is essentially intangible and doesn't result in the ownership of anything. The concept of service quality was based upon the theories of customer satisfaction proposed in Europe and the Americas (Garvin, 1988). Lee (2016) mentioned that service quality is an extension of the consumer's evaluation of an object or service received. (Parasuraman \& Zeithaml, 1985) pointed out that service quality would be the level of added excellence after meeting the customers' requirements, or the level of control over variables that could be achieved when pursuing excellence. Service quality is basically intangible, and does not result in changes to ownership even after the service has been delivered. Masrurul, (2019) defined service quality as a realistic and cognitive discrepancy between experiences-based norms and performances concerning service benefits. In the hotel industry a quality service is reflected in cleanliness, safety, maintenance of rooms and considerate attitude of staff (Samori \& Sabtu, 2014).

Hotel sector is also a service sector industry, playing a crucial role internationally and locally attracting travellers offering theme innovative facilities. A hotel providing good quality service at all times can attract a number of customers. Success of hotel sector is directly depended on service quality. (Parasuraman \& Zeithaml, 1985) believed that service quality is a result of comparisons between the consumers' expectation and actual performance of the services. The concept of service quality (perceived services - expected services) was used to provide additional definitions. Service quality assessments not only include the results of the services, but also the means by which it was delivered as well. Lee and Cheng (2018) described quality as the excellence of a product or service determined by the customer. Quality assessments therefore include positive connotations of the experience.

Service quality is considered the life of any business (Gorondutse \& Hillman, 2014) and core of service management (Samori \& Sabtu, 2014). Most hotels have similar facilities in the current competitive environment; the survival of hotels depends on the delivery of service quality resulting in customer satisfaction (Masrurul, 2019). According to Wilkins et al., (2007) there are three main types of service quality in hotels; physical product, service experience and quality of food and beverages. Service quality is related with customer satisfaction (Masrurul, 2019) and customer satisfaction is associated with customers revisit intention (Samori \& Sabtu, 2014). If an effective image is portrayed to customers, it will create competitive advantage for hotel (Tessera, 2016) 
It has been noted that service quality is the greatest differentiator among service providers (Hayes, Ninemeier $\&$ Miller, 2011), there has been no clear-cut definition of service quality. Preceding research has acknowledged that customers evaluate the service experience [Experience] by comparing what they want or expect [Expectations] to what was received (Parasuraman, et al., 1985; 1988; 1990). Service quality is affected by employee motivation, perishability, tangible dimensions of the hotel and materials associated with the service (Masrurul, 2019).

Service quality dimensions are more difficult to define than product quality dimension. Services and products share many attributes, services have more diverse quality attributes than products. This often results from wide variation created by high customer involvement. Customers employs many tangible aspects to judge quality; style, hardness, colour, label, feel, and package when purchasing goods. However, when purchasing services fewer tangibles aspects exist to evaluate quality; customers depend on other aspects to evaluate service quality. Service quality dimensions are the aspects or characteristics which customers use to evaluate service quality. Parasuraman et al., (1985) identifies ten dimensions that influence customer's perceptions of service quality as reliability, responsiveness, tangibility, communication, credibility, security, competence, courtesy, understanding and access. (Delgado-Ballester, 2004) identified five dimensions of service quality which are tangibles, reliability, responsiveness, assurance and empathy.

According to (Delgado-Ballester, 2004) and Parasuraman et al., (1988); tangible service quality dimension refers to the appearance of the physical surroundings and facilities, equipment, personnel and the way of communication. For instance, how the room is set in a hotel gives the tangible aspect in a service. A unique first hand impression would make customers more likely to return in the future. In the hotel industry tangibility can be generalised (Ali, et al., 2017). Managers should pay more attention to the physical aspects of the service quality as customers gave lowest ranking of quality compared to expectations in the tangible dimension (Aldehayyat, et al., 2011). Hotels rely heavily on tangibles as guest usually predict quality of services on the quality of physical environment and tangible facilities.

Reliability is how the company performs and completes the promised service dependably and accuracy within the given set of requirements between the company and the customer (Delgado-Ballester, 2004). Parasuraman, et al., (1990) summarised reliability to mean getting it right first time, honouring promises and dependability of the service provider. Bruhn and Grund (2006) suggested that reliability cannot be interpreted as a quality dimension because this feature can concern several quality dimensions. Having a room ready upon check-in is an example of the reliability dimension. An organisation's ability to deliver is the important factor in providing service quality.

According to (Delgado-Ballester, 2004) and (Parasuraman, et al., 1990); responsiveness service quality refers to the willingness of the company to help its customers in providing them with a good, quality and fast service. Every customer feels valued if they get the best possible quality in the service. Masrurul, (2019) posits that excellent service embrace responsiveness, employees showing passion for service and for their work and ability to deal with emergencies. Customers judge a company responsiveness by assessing the amount of time it takes and attention given in response to their requests, questions, complains and problems. Responding quickly to requests or complains leads to a higher rating on this dimension. Hospitality managers should train their personal to offer polite, respectful and friendly service (Ali, et al., 2017).

Assurance service quality refers to company employees skilled workers who are able to gain the trust and confidence of the customers (Delgado-Ballester, 2004). If customers are not comfortable with the employees, there is likelihood that they will not visit the company again. Parasuraman, et al., (1990) dimension of service quality defined assurance as possession of the skills and knowledge required to perform the service thus competence. Employee's knowledge, politeness and trustworthiness assure customers of good quality service (Parasuraman, et al., 1990). This dimension is very important in services that give high levels of credibility to quality like in motor vehicle repair and medical services. Assurance increases in proportion to the risk and the greater the inability for a customer to evaluate the service.

According to (Delgado-Ballester, 2004) empathy service quality is how the company cares and give individualised attention to their customers, to make the customers feel extra valued and special. Empathy is willingness and capability to respond to individual customer desires (Parasuraman et al.; 1988). Making the bed with sheets of a 
particular colour as requested by the customer is an example of empathy as given by (Delgado-Ballester, 2004) and this improves level of customer perception. This dimension is a combination of reliability, responsiveness and assurance. Repeat business is obtained if customers feel that they get individualised and quality attention. Customers want to be recognised and given individualised service.

A number of authors tested service quality dimensions comprehensiveness using management perception of service quality and others using customers perception of service quality. A summary of service quality dimensions in the hospitality sector from the literature is presented in the table 1.

Table 1: Service quality dimensions postulators

\begin{tabular}{|l|l|}
\hline Author & Service quality dimensions \\
\hline Parasuraman et al., (1988) & Tangibles, reliability, responsiveness, assurance, empathy \\
\hline Gronroos (1990) & Technical, functional and perceived service \\
\hline Johnston and Silvestro (1990) & $\begin{array}{l}\text { Access, appearance, availability, cleanliness, comfort, } \\
\text { communication, competence, courtesy, friendliness, } \\
\text { reliability, responsiveness, security, commitment, } \\
\text { helpfulness, functionality, and integrity. }\end{array}$ \\
\hline Mei et al. (1999) & Employees, tangibles, reliability \\
\hline Saleh and Ryan (1991) & $\begin{array}{l}\text { Conviviality, tangibles, reassurance, avoid sarcasm, } \\
\text { empathy, }\end{array}$ \\
\hline Knutson et al. (1990) & Reliability, assurance, responsiveness, tangibles, empathy \\
\hline Juwaheer (2004) & $\begin{array}{l}\text { Room attractions, decor factors, hotel surroundings, } \\
\text { environmental factors, }\end{array}$ \\
\hline Delgado and Ballester (2004) & $\begin{array}{l}\text { Tangibles, reliability, responsiveness, assurance and } \\
\text { empathy }\end{array}$ \\
\hline Khan (2003) & $\begin{array}{l}\text { Tangibles, eco tangibles, reliability, assurance, } \\
\text { responsiveness, empathy }\end{array}$ \\
\hline Getty and Getty (2003) & $\begin{array}{l}\text { Tangibility, reliability, responsiveness, confidence, } \\
\text { communication }\end{array}$ \\
\hline Albecete-Saes et al (2007) & $\begin{array}{l}\text { Personal response, complementary offer, tourist relations, } \\
\text { tangible elements, empathy }\end{array}$ \\
\hline
\end{tabular}

Service quality influences customer level of satisfaction (Kasiri, et al., 2017). Customer satisfaction is a business philosophy which tends to be the creation of value for customers, anticipating and managing their expectations, and demonstrating ability and responsibility to satisfy their needs. Service quality and customer satisfaction are critical factors for success of any business (Gronroos, 1990; Parasuraman \& Zeithaml, 1985). The key to achieve sustainable advantage lies in delivering high quality service that result in satisfied customers. Service quality and customer satisfaction are key factors in the battle to obtain competitive advantage and customer retention.

Customer satisfaction is the outcome of customers' perception of the value received in a transaction or relationship, where value equals perceived service quality, compared to the value expected from transactions or relationships with competing vendors (Ali, et al., 2017). Many researchers (Gorondutse \& Hillman, 2014; Masrurul, 2019; Tessera, 2016) conceptualise customer satisfaction as an individual's feeling of pleasure or disappointment resulting from comparing a product's perceived performance in relation to his or her expectations. Customer satisfaction can be shown in the figure 1 below. 
Figure 1: Customer satisfaction - Gap Model of service quality

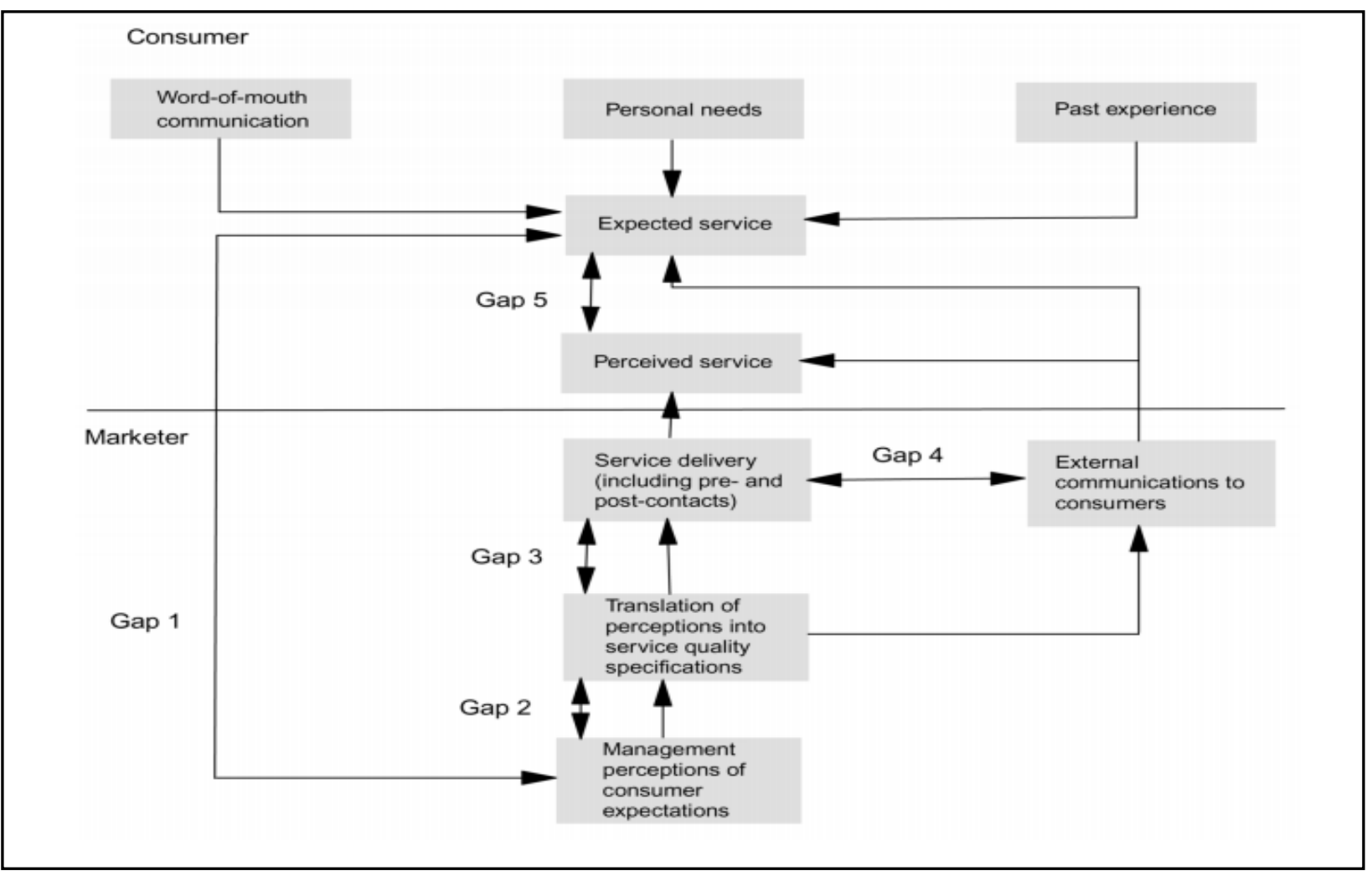

Source: Parasuraman, Zeithaml and Berry; (1985)

\subsection{SERVQUAL}

Service quality measuring is a very important part in the quality enhancement process as it gives feedback about type of service offered and level to which it meets customer's requirements (Jankalova, 2016). SERVQUAL is one of the most used and well acknowledged models used by researchers in measuring service quality in hotels (Parasuraman et al., 1998). The SERVQUAL instrument was first intended to measure the variance between quality expectations and perceived service through focusing on five dimensions of service quality which are tangibles, reliability, responsiveness, assurance, and empathy (Jankalova, 2016). With acknowledgement of SERVQUAL by many researchers it was later applied in a number of hotel studies to measure service quality (Rauch, et al., 2015; Mugondi, 2015; Watiki, 2014; Ali, et al., 2017; Masrurul, 2019; Tessera, 2016). The SERVQUAL model is particularly important in classifying service quality parameters however several researchers have raised interrogations about indistinctness and scope of dimensions in measuring service quality. Wu and Cheng (2013) also pointed out the limitations of the SERVQUAL model, arguing that the model fails to adequately measure all aspects of service performance. Masrurul (2019) contended that the model essentially emphasises on the single dimensional concept only.

Accordingly, as a result some modifications of the model changed and these comprised the LODGEQUAL, DINESERV, DIVERPER, HISTOLQUAL and HOLSERV (Getty \& Getty, 2003; Ladhari, 2009). These modifications looked like amendments of model to match size of hotel, nevertheless still could not service the requirements of the hotel and tourism industry. Their major weakness has been that they were mainly developed for process outcomes as opposed to the service outcomes they were intended to measure (Nguyen \& Wang, 2011). A simple theoretical framework is depicted from literature. From the literature it can be summed that service quality is determined by customers' experience perceptions and expectations. 


\section{Theoretical framework}

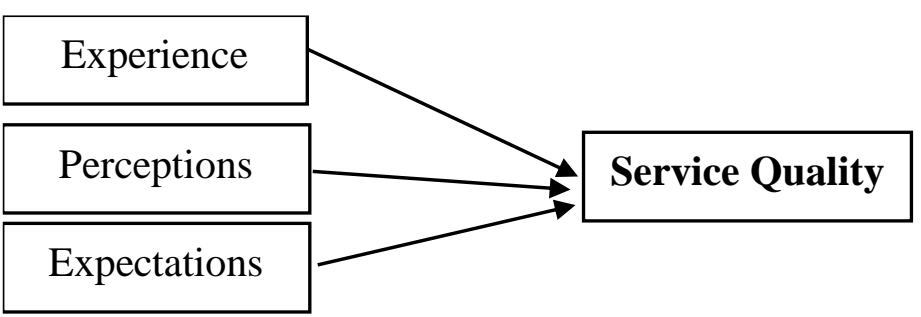

\section{STUDY PURPOSE}

The main objective of this investigation was to investigate customers' perceptions, expectations and experiences of service quality in hotels in Mutare, Zimbabwe from December 2018 to January 2020. To asses service quality level in hotels during festive season and to analyse customer service concerns using SERVQUAL service quality dimensions.

\section{RESEARCH METHODOLOGY}

The study uses Netnography- analysing reviews written on online travel platforms to establish the customers' expectations, perceptions and expectations of service quality of hotels. Netnography is the branch of ethnography that analyses the free behaviour of individuals on the internet to provide useful insights (Basera \& Nyahunzwi, 2019). (Kozinets, 1998) defined netnography as " a written account resulting from fieldwork studying the cultures and communities that emerge from online, computer mediated, or internet-based communications, where both the field work and textual account are methodologically informed by the traditions and techniques of cultural anthropology".

The term Netnography is a blend of internet and ethnography. The researchers used netnography because it is quicker (reflexivity), modest and less expensive than ethnography, data was often abundant and easy to obtain. Netnography presents diverse customers that use a tourism facility and willing to share their experiences online (Baka, 2016) and it allows the researcher opportunity to explore new phenomena that can not be explored using conventional methods of data collection (Wu \& Pearce, 2014). Netnography helps to overcome the problem of access to research participants as researchers do not need travel to study sites and seek permission from tourist managers but can access participants just through a button click.

The study information gathering site was TripAdvisor.com website. The website was chosen because it is the biggest travel website with all inclusive tourist experience unit of analysis (Walker \& Moscardo, 2016). The study focussed on the hotels in Manicaland and the researchers searched terms "customers reviews of hotels in Mutare Zimbabwe' on TripAdvisor.com. Fifteen hotels popped up and only eight hotels were selected after a diligence exercise of checking if they are registered as hotels with Zimbabwe Tourism Authority and has customer reviews. The researchers gathered reviews that were recorded between January 2017 and December 2019. A total of one hundred and twenty-two reviews were generated and the researchers purposively selected only those reviews that focused on service quality. Thirty three reviews were selected and these were on a word document. All the reviews were throughly read through and the reviews with customers' perceptions, expectations and experience of service quality of hotels as guided with SERVQUAL dimension were considered. SERVQUAL dimensions and sub themes were used to do content analysis. The analysis of the data involved coding the data manually, by reading it through not less that two times making interpretive field notes about the customers' expectation, perception and experience of service quality of hotel. 
This investigation has its own limitations which include that majority of the respondents did not state their places or countries of origin and this is common as (Mkono, \& Tribe, 2016) highligted in their research. Ethical consideration is another limitation in netnograogy as initially set by Kozinets (1998) that researchers must be participant observers. The researcher adopted a 'lurker approach' which excludes the researcher partaking in oline interaction with the feeling that partaking in online discussion would affect annonymity of reviewers. The reviews have not been amended to correct linguistic or spelling mistakes and are presented as they are. The author also used reflexivity methodology to construe results of this study in addition to TripAdvisor reviews. The authors' acquintance and knowledge of service quality of hotels prejudiced the explanation of the results.

\subsection{Case study context}

The researchers sought to understand the tourist perceptions, expectations and experiences of the service quality of accommodation products in Manicaland province, Zimbabwe. Zimbabwe is divided into ten adminstrative provinces and Manicaland is located in the Eastern region; bordering Mozambique. Mutare is Manicaland's provincial city and other towns and districts in the province include; Nyanga, Chipinge, Chimani mani, Vumba, Rusape and Buhera. The province is endowed with tourism resources and activities that include; Wildlife (Nyanga National Park), vegetation: forest (Chirinda forest), tea plantations (Tanganda Tea Estates), botanical gardens (Vumba, Nyanga), Culture (cultural festivals and traditional dances), nature based: mountains (Mount Inyangani and Vumba Mountains), beautiful scenery; water based: waterfalls (Mutarazi), Birchneough bridge and dams (Osborne dam). There are a number of accommodation providers in Manicaland and such hotels as Leopard Rock and Rhodes Nyanga are attractions in their own right because of their history.

Despite the different types of accommodation offered in Manicaland it must be noted that notable providers are concentrated in Mutare, Nyanga and Vumba. The reasons being proximity to the border and the benefits of being closer to attractions and the provincial capital. The accommodation providers are owned and managed by different organisations that range from international brands (Holiday Inn- IHG), Amber (African Sun) to proprietory businesses (Gordon's ) The researchers identified case hotels in order to draw conclusions relating to tourist service experiences. The case hotels are Leopard rock, Gordon's, Manica Skyview, Musangano, Eden Lodge, Mutare Amber Hotel, Christmas Pass Hotel and Holiday Inn Mutare. All the accommodation providers are registered with the ZTA and none of them are five star rated and only the Leopard Rock and Holiday inn are the highest rated ( four star). Christmas Pass hotel and Eden Lodge are the least graded among the case hotels. Only Manica Skyview and Holiday Inn are located in the city centre and the rest are resort hotels. The case hotels offer different room types which include; budget, standard, deluxes and suites. They also provide other products that augment the accommodation product and these include; wedding venues, conferencing facilities, nature walks, mountain climbing and sporting activities ( golfing and fishing). The selected case hotels provided a platform in which the service quality was analysed. It must be noted that the case hotels are not representative of the accommodation providers in Manicaland but representative of themselves. Nonetheless, they provide interesting entry points that help to draw conclusions relating to tourists' views with relation to service quality in Manicaland.

\section{FINDINGS AND DISCUSSIONS}

The study details the level of service quality offered by hotels in Manicaland, Zimbabwe. The participants' narratives obtained from Tripadvisor are used to derive positives and shortcomings relating to case hotels' quality of service and also bring to the fore areas that customers value most when assessing the same. An analysis of the emerging case hotels' data was based on the five Servqaul dimensions.

\subsection{Profiling the participants}

The researchers identified thirty-three hotel guests whose comments specifically refer to service quality dimensions. The characteristics of the reviewers are summarized in the table 2 below:

Table 2: Characteristics of the reviewers

\begin{tabular}{|l|l|l|l|l|l|l|l|l|l|l}
\hline Service provider & $\begin{array}{l}\text { Reviewer's } \\
\text { code }\end{array}$ & Total reviews & Photos & Comment viewed as helpful \\
\hline
\end{tabular}




\begin{tabular}{|c|c|c|c|c|c|}
\hline \multirow[t]{5}{*}{ Gordon's } & G1 & 17 & Yes & & UK \\
\hline & $\mathrm{G} 2$ & 12 & No & & Zim \\
\hline & G3 & 98 & No & 44 & Zim \\
\hline & G4 & 31 & No & 1 & -- \\
\hline & G5 & 43 & Yes & 3 & UK \\
\hline \multirow[t]{4}{*}{ Eden Lodge } & E1 & 13 & No & & Zim \\
\hline & E2 & 4 & No & 6 & -- \\
\hline & E3 & 9 & -- & 12 & \\
\hline & E4 & 144 & -- & 41 & SA \\
\hline \multirow[t]{4}{*}{ Manica Skyview } & M1 & 5 & & & Zim \\
\hline & M2 & 2 & & 1 & -- \\
\hline & M3 & 231 & & 42 & Zim \\
\hline & M4 & 5 & & & \\
\hline \multirow[t]{5}{*}{ Holiday Inn } & H1 & 4 & Yes & & Zim \\
\hline & $\mathrm{H} 2$ & 3 & & & Zim \\
\hline & $\mathrm{H} 3$ & 2 & & & Germany \\
\hline & $\mathrm{H} 4$ & 59 & & 9 & \\
\hline & H5 & 12 & & 2 & \\
\hline \multirow[t]{4}{*}{ Leopard Rock } & L1 & 116 & & 47 & UK \\
\hline & L2 & 31 & & 10 & Zim \\
\hline & L3 & 14 & & 28 & SA \\
\hline & L4 & 3 & & 2 & \\
\hline \multirow[t]{5}{*}{ Musangano } & MU1 & 48 & & 14 & SA \\
\hline & MU2 & 1 & & & \\
\hline & MU3 & 2 & & & Germany \\
\hline & MU4 & 1078 & & 192 & SA \\
\hline & MU5 & 25 & & 43 & Germany \\
\hline \multirow[t]{3}{*}{ Amber } & A1 & 2 & & 110 & SA \\
\hline & A2 & 40 & Yes & 70 & Zim \\
\hline & A3 & 3 & & 13 & \\
\hline \multirow[t]{3}{*}{ Christmas Pass } & $\mathrm{C} 1$ & 18 & Yes & 2 & \\
\hline & $\mathrm{C} 2$ & 15 & & 1 & Zim \\
\hline & $\mathrm{C} 3$ & 5 & & 1 & \\
\hline
\end{tabular}

The researchers identified thirty-three reviewers whose comments specifically refer to service quality. The reviewers were identified using codes and listed without any rank or formality in order to conceal the identity of the participants. They were only categorised according to the hotel in which specific comments were referred to facilitate meaningful conclusions to be drawn. That is, the case hotels are representative of themselves and however, contribute to the aggregate service quality perceptions and experiences of Manicaland hotels. The dominant language used by the reviewers was English and google translation was used for one review made in Portuguese. The reviewers used pseudo names as identification which further concealed their identity and also made it difficult for the researchers to differentiate the participants on the basis of either age or gender. $30.3 \%$ of the total reviewers revealed their country of origin and $69.7 \%$ of them are locals. This resonates well with (Varki \& Colgate, 2001) conclusions that hotel customers are mostly residence of the country in which the hotel is situated.

The majority of the participants are well travelled, knowledgeable and experienced guests. An analysis of the reviewers' profiles indicate that MU4 and L1 for example have respectively reviewed 1078 and 116 places they have visited. L1 in particular, shared photographs of the places he had visited which illustrates that indeed he is well travelled and is in a position to offer meaningful insights relating to case hotels' service quality. Furthermore, A2 clearly said, "My work requires a lot of travelling, I travel throughout Zimbabwe. Then I have also been to South Africa and Tanzania on my work place business". This reveals that he has experienced hotel products in different countries and can easily evaluate the service quality of Manicaland hotels and conclude that ".....is the best" from an informed view. The participants' comments provide other reviewers with insights that help them to make their choices of hotel accommodation supports that the participants are knowledgeable. In this case, fortythree trip advisor reviewers pointed that MU5's review as helpful and forty-four indicated the same for G3's review as well.

\subsection{Tangibles}


The participants assessed the service quality of case hotels based on bed comfort, room and bathroom cleanliness, furnishings and food taste. Twenty-one reviews centred on the tangibles dimension with fifteen of them relating to the bed. This is in sync with Zeithaml \& Bitner's, (2003) conclusions that customers evaluate service quality based on the tangibles dimension. Eight-five percent of the participants concluded that the case hotels offered comfortable beds. In this case, G4 said that the beds are "...the most comfortable in the whole of Manicaland" and A1 views the beds as "...comfortable". The participants also pointed out that one aspect can influence the overall service quality, for example; “...... beds are super comfortable with new linen" -C1; ".....however, they should improve on their showers, ........showers not working". In addition, C1's disgruntlement that the showers are not working shows that customers' perception of a quality hotel product is not only influenced by the bed comfort. It encompasses other tangible elements and the participants indicated that room cleaniliness, hot water, lighting, good lighting, flushy toilets and food as aspects that also influence their hotel experience. The participants complained about poor working showers and windows not closing properly in five of the eight case hotels.

The participants also showed great interest in the food offered by the different establishments. Apart from A1 who highlighted that "the menu was limited" all the participants who commented about the food were impressed by the food quality. "..breakfast was exceptional on both trips"- G2: this indicates that the hotel is able to maintain the service quality of the food it offers. More so, it is imperative to note that the reviewers have diverse backgrounds that influence their perception of the food quality. The ability of the hotels to meet the expectations of the customers from diverse backgrounds depicts that the hotels offer quality food services. Nonetheless, the reviews did not highlight the nature of the food that is served and its health attributes.

The participants' perception of service quality is influenced by past purchase experience as C3 notes that, "The furnishings are the same I used 2 years ago, ....... sincerely hope that the owners invest in this business before they lose customers" In the same vein ,C1 said; "I cannot rate it very good ---I would stay here again". As such, C3's assumption that the hotel might lose customers is influenced by the previous purchase of the same product and not the actual product quality.

\subsection{Responsiveness}

The researchers also noted that the hotel guests expressed their views relating to the hotel employees' ability to provide prompt service (Mmutle \& Shonhe, 2017) and assisting the guests during service delivery. Hotels in Manicaland performed well on this dimension and L4 summarised the employees' performance as "........ excellent service......." and when referring to a particular hotel MU2 stated that, "... the entire staff is helpful" during the entire stay. This clearly shows that the hotels were able to meet guest expectations. There are also other organisations that performed below guest expectations; "I got zero recognition from staff wandering around the place"-E3. The researchers concluded that in this instance, the employees were found wanting because they had experienced high levels of demand (taking into account that E3 visited the hotel on the Christmas Eve). E2 visited the same hotel in August and found out that the staff were "....very friendly and helpful". E2's review thus confirms the researchers' earlier observation that the promptness is influenced by levels of demand. Also (Kotler \& Armstrong, 2008b) noted that service variability among employees may be a result of lack of clearly laid procedures and different employees will come up with different ways of handling situations.

\subsection{Assurance}

Only two guests evaluated the hotels' service quality in terms of the ability of the employees to inspire confidence and trust that the hotel product will meet customer expectations. The assurance depends on the hotel guests' intuition and judgement of whether the actual hotel product performance match expected performance. From this perspective, L4 noted, “......cannot help but relax and will receive a service and spoils from Lazarus and his colleagues that is unmatched". Such narratives denote that the customer is satisfied with the actual performance. The ability of the hotel employees to communicate effectively and exhibit knowledge not only about the hotel products but also the surroundings, help to build positive perception about product performance in the minds of the hotel guests. G3 said, ".....offers a wealth of advice on what to do and where to eat in the area and being so centrally located in Manicaland, along with all the small and personal touches to make this more than just an 
overnight stop". The inability of the customers to comment on this aspect might be an indication that the hotel employees failed to meet customer expectations.

\subsection{Empathy}

(Mmutle \& Shonhe, 2017) relates empathy as the extent to which employees offer personalised service and the employees' knowledge skills and courtesy is handy on this dimension. "We were met and taken around by an extremely enthusiastic and effective manager.... He showed us the hotel explaining in great detail its history, layout and the strengths of the venue as a destination wedding" $-\mathrm{L} 1$. The above comments depict that employee skills assist in positively positioning the hotel's service quality in the hotel guest's mind. The employee performances are part and parcel of the tourism product and contribute in reinforcing hotel guests' perceptions and experiences of service quality.

\subsection{Reliability}

The hotel is guaranteed of positive word of mouth recommendations and repeat business when they offer excellent service consistently (Kleynhans \& Zhou, 2012). Mmutle \& Shonhe, (2017) pointed out that service failure may be caused by poor internet connections and dysfunctional hotel equipment and C1 said, "Wifi worked ok not for streaming but you can send emails and do basic browsing". He concluded by casting doubts on the product's performance when he said, "I can't rate it good". Additionally C2 indicated that, "....showers not working" on the same hotel but during different periods of stay. These reviews result in potential hotel guests drawing conclusions that the particular establishment's product offering is inconsistent because of the defects pointed by $\mathrm{C} 1$ and $\mathrm{C} 2$. Contrastingly, L1 observed that, ".... all facilities are in tip top condition" and E1 noted that "showers were functional, hot water..." at another hotel. The reliability of the equipment at another hotel led G1 to aptly say, “......don't stay anywhere else in Mutare".

The customer experiences were evaluated against the SERVQUAL dimensions in order to draw conclusions regarding service quality amongst hospitality organisations in Manicaland province, Zimbabwe. The review of customer comments made on Trip Advisor indicate that most hotels still lack basic service standards and the most cited were room cleanliness, product functionality and timely delivery of services. The customers noted that improvements have to be made on bathroom fittings, lighting and internet connections; prompting the need for hotels to conduct deep cleaning and make necessary renovations. The customers' comments reinforce Zhang, Ye, \& Law's, (2011) assertion that guest room amenities have an influence on customers' perception of service quality. A closer analysis reveal that small hotels are not able to match customer expectations and the more established ones matched and/ exceeded customer expectations.

The study used an outcome based approach to evaluate the service quality of hospitality products in Manicalnd Province. The comments made on Trip Advisor provided insights of the customers' service encounters and their perception of service quality. The researchers acknowledge that drawing conclusions about service quality based on customer comments made on Trip Advisor only overlooks the experiences and evaluations of those who did not comment or commented elsewhere. Nonetheless, it is imperative to note that customer perspectives provide insights of own customers perspectives and contributions towards defining service quality. Ntimane and Tichaawa, (2017) and Kleynhans and Zhou, (2012) made use of customer perceptions to draw conclusions regarding service quality of hospitality organisations located in the Gauteng province and Pretoria respectively. This is so because customer experiences assist in positioning the hospitality organisations' products and services against customer expectations (Zhang et al., 2011).

Ntimane and Tichaawa, (2017) state that service quality is influenced by employee performance and this research noted that the hospitality customers are more travelled, knowledgeable and demanding. The implication is that hospitality organisations need to initiate a holistic and integrated approach that is, consider all the variables that have an influence the customers' evaluation of service quality. In addition, the customer might be delighted today because of there is internet connections and on the next visit the customer not only demands the organisation to be reliable in providing the internet services but will also have new expectations that also influence their perception of the service quality 


\section{CONCLUSION AND RECOMMENDATION}

The objective of the study was to use Netnography to evaluate the customers' perceptions, expectations and experiences of service quality in hotels in Manicaland. The study contributes to service quality management in hotels from the perspective of customers. The customers are key stakeholders in hotel management and their reviews means a lot to sustainable management of hotel facilities. The results pointed that there is a marked gap between service expectations and experiences on the tangible elements. Although the hotels offered clean rooms and comfortable beds, the customers raised concerns on the lighting, absence of phones, showers not working and absence of hot water. The researchers concluded that much of the concerns were raised by customers who visited lowly graded hotels such as Christmas Pass. This calls for the ZTA to conduct regular checks and ensure that the hotel establishments provide the basic amenities. The service providers themselves need to conduct deep cleaning, during periods of low demand there is need to replace old taps, fix windows and repaint the walls if necessary. This will ensure that all hotel accessories are working properly.

Seventy percent of the participants were able to pick some product defects which shows that the service quality has room for improvement. The accommodation product not only focuses on the bed but also other items as employee performance, physical evidence and the décor also influence the overall guest experience. The hotel managers need to keep visiting customer reviews on Trip Advisor.com and other online platforms so that they improve the quality of service they provide as per customers' expectations. The researchers realized that only three of the eight case hotels interacted with the customers and responded to the comments made on Trip Advisor. It is interesting to note that these hotels also had positive comments made especially in 2019 , indicating that their decisions are informed by the comments made by the customers.

Further suggestions and recommendations that can be drawn from the customers are that the hoteliers need to ensure prompt response to customer complains. There has to be service recovery strategies in place and the employees have to be proactive in order to anticipate the customer's likely demands. In this case, the reservations department has to gather as much detail relating to the customers' purpose of travel, room type and service expectations so that they would match or exceed these expectations. Service quality can also be enhanced by creating a customer database that captures the customers' information which will form the basis of improving service quality. The customers' expectations are shaped by past purchase behaviour (Zeithaml \& Bitner, 2003) the database will provide the hotels with information that help to determine the future buying patterns of the customers.

The customers indicated that the hotels offered quality food; the researchers recommend that the hotels create promotional material that emphasise the quality and uniqueness of the food they offer. This will increase the guest spending at the hotels, all the same, the hotels should communicate what they actually can deliver. The promotional materials are also key in determining customer expectations (Kotler \& Armstrong, 2008) and the service providers have to make use of pictures drawn from the establishment for example, so that customers can build an image of service expectations based on what the hotel can offer. In perspective of SERVQUAL it can be concluded that;

Tangibles: The hotels are supposed to be equipped with recent equipment, modern beds and pillow, rooms and public areas should be very clean

Responsiveness: The hoteliers need to respond to customers promptly regarding complains or service provision. Swift check in and check out.

Assurance: Provision of service should be time guaranteed.

Empathy: Hotel employees need to be part of the service they are offering and doing it whole heartedly with diligence, politely, and utmost dedication.

Reliability: The hotel management systems should be dependable from billing and provision good meals. The employees should be relied on the same as the management systems. 


\section{LIMITATIONS}

It must be noted that the case hotels are not representative of the accommodation providers in Manicaland but representative of themselves. Nonetheless, they provide interesting entry points that help to draw conclusions relating to tourists' views with relation to service quality in Manicaland. Other review platforms besides trip advisor need to be interrogated to compare the findings.

\section{ACKNOWLEDGEMENTS}

I would like to acknowledge that this is an extension of my PHD thesis titled 'Factors contributing to the late adoption of quality management systems in the hotel sector in Zimbabwe'. Most of the work is extracted from the thesis.

\section{References}

Alauddin, M., Ahsan, S. H., Mowla, M. M., Islam, M., \& Hossain, M. (2019). Investigating the Relationship between Service Quality, Customer satisfaction and customer loyalty in the hotel industry: Bangladesh perspective. Global Journal of Management and Business Research, 19(1).

Baka, V. (2016). The becoming of user-generated reviews: looking at the past to understand the future of managing reputation in the travel sector. Tourism Management., 53(148-162).

Basera, V., \& Nyahunzwi, D. K. (2019). The Online Marketing Strategies of the Zimbabwe Tourism Authority (ZTA) and South Africa Tourism (SAT): A Comparative Study. Journal of Tourism and Hospitality Management, $8(1)$.

Garvin, D. A. (1988). Managing Quality. The Strategic and Competitive Edge. New York: The Free Press.

Getty, J. M., \& Getty, R. L. (2003). Lodging Quality Index (LQI): Assessing Customers' Perceptions of Quality Deliver. International Journal of Contemporary Hospitality Management, 15(2), 94-104.

Gorondutse, A. H., \& Hillman, H. (2014). Mediation effect of customer satisfaction on the relationships between service quality and customer loyalty in the Nigerian foods and beverages industry. International Journal of Management Science and Engineering Management, 9, 1-8.

Gronroos, C. (1990). Relationship approach to marketing in service contexts: The marketing and organizational behavior interface. Journal of Business Research, 20.

Hayes, K. D., Ninemeier, D. J., \& Miller, A. A. (2011). Foundations of Lodging Management. London: Pearson Education.

Jankalova, M. (2016). Service Quality—Object of Business Excellence Measuring. Review of European Studies, $8(2)$.

Kleynhans, I. C., \& Zhou, P. (2012). Service quality at selected hotels in Pretoria, South Africa. African Journal of Business Management, 6(45), 11342-11349. https://doi.org/10.5897/AJBM12.1132

Kotler, P., \& Armstrong, G. (2008a). Principles of Marketing. (12th ed.). New Delhi: Pearson Education.

Kotler, P., \& Armstrong, G. (2008b). Principles of Marketing (12th ed.). New Delhi: Pearson Education.

Kozinets, R. V. (1998). On netnography: Initial reflections on consumer research investigations of cyber culture. Advances in Consumer Research, 25, 366-371.

Ladhari, R. (2009). Service quality, emotional satisfaction, and behavioural intentions: A study in the hotel industry". Managing Service Quality:. An International Journal, 19(3), 308-331. 
Masrurul, M. M. (2019). Impact of Service Quality on Customer Satisfaction in Bangladesh Tourism Industry: An Empirical Study. Advances in Management, 12(1).

Mkono, M. \& Tribe, J. (2016). Beyond reviewing: uncovering the multiple roles of tourism social media users. Journal of Travel Research, 56(3), 1-12.

Mmutle, T., \& Shonhe, L. (2017). Customers' perception of Service Quality and its impact on reputation in the Hospitality Industry. African Journal of Hospitality, Tourism and Leisure, 6(3), 1-25.

Parasuraman, A., \& Zeithaml, V. A. (1985). A conceptual model of service quality and its implications for further research. Journal of Marketing, 49(46).

Samori, Z., \& Sabtu, N. (2014). Developing halal standard for Malaysian hotel industry: An exploratory study. Procedia-Social and Behavioral Sciences, , 12(1), Pp. 122-157, 12(1), 122-157.

Tessera, F. A. (2016). Service Quality and Hotel's Customer Satisfaction: An Empirical Evidence from Ethiopia. Electronic Journal of Business and Management, 1(1), 24-32.

UNWTO. (2019). UNWTO World Tourism Barometer and Statistical Annex. Madrid.

VA, Z., \& Bitner, M. . (2003). Services marketing. New York: McGraw-Hill.

Varki, S., \& Colgate, M. (2001). The role of price perceptions in an intergrated model of behavioural intentions. Journal of Services Research, 3(3), 232-240.

Walker, K., \& Moscardo, G. (2016). Moving beyond sense of place to care of place: the role of Indigenous values and interpretation in promoting transformative change in tourists' place images and personal values. Journal of Sustainable Tourism, 24(8-9), Pp. 1243-1261, 24(8-9), 1243-1261.

Zhang, Z., Ye, Q., \& Law, R. (2011). Determinants of hotel room price: an exploration of travellers' hierarchy of accommodation needs. International Journal of Contemporary Hospitality Management, 23(7), 972-981. 